\title{
PENGEMBANGAN INSTRUMEN ASESMEN KEBUTUHAN PERKEMBANGAN UNTUK PENYUSUNAN KURIKULUM DAN EVALUASI PROGRAM BK
}

\author{
Gendon Barus \\ Bimbingan dan Konseling FKIP USD Yogyakarta \\ Mrican, Tromol Pos 29, Yogyakarta 55002 \\ bardon.usd@gmail.com
}

\begin{abstract}
Abstrak
Penelitian pengembangan ini bertujuan menghasilkan instrumen asesmen kebutuhan peserta didik, disebut Invantori Kebutuhan Perkembangan Murid (IKPM). Penelitian mengikuti model Plomp (1999) dengan lima fase. Reliabilitas instrumen diestimasi dengan teknik Alpha Cronbach, validitas isi diperiksa oleh pakar dan telaah praktisi melalui FGD. Validitas empirik dan kecocokan model pengukuran dibuktikan dengan analisis faktor konfirmatori (CFA) dengan program Lisrel 8.30. Telaah praktisi melibatkan 60 orang guru kelas V dan VI SD dalam dua tahap FGD, sedangkan uji coba empirik dan implementasi melibatkan murid kelas V dan VI. Hasil penelitian pengembangan ini adalah: 1) IKPM dapat digunakan untuk menghimpun data kebutuhan perkembangan sebagai dasar penyusunan kurikulum bimbingan dan melaksanakan evaluasi program, bimbingan dan alat ukur evaluasi program bimbingan klasikal di sekolah dasar dan 2) teridentifikasi butir-butir kebutuhan perkembangan murid yang intens dan sangat intens untuk dipenuhi melalui layanan bimbingan klasikal.
\end{abstract}

Kata kunci: instrumen asesmen kebutuban, kurikulum bimbingan, instrument evaluasi program BK 


\title{
DEVELOPMENT OF DEVELOPMENTAL NEEDS ASSESSMENT INSTRUMENT FOR CURRICULUM ARRANGEMENT AND EVALUATION OF BK PROGRAM
}

\author{
Gendon Barus \\ Bimbingan dan Konseling FKIP USD Yogyakarta \\ Mrican, Tromol Pos 29, Yogyakarta 55002 \\ bardon.usd@gmail.com
}

\begin{abstract}
The goal of this research is to produce a developmental needs assessment instrument, called Student's Developmental Needs Inventory, which can be use to reveal the needs of students in elementary school. The research method follows the model of Research and Development (R \& D) by Plomp (1999) with five phases. The instrument which is developed in this study guidance and counseling (Bimbingan Konseling, BK) in elementary school. Instrument reliability is estimated using by Alpha Cronbach technique, it content validity is checked by experts judgment and practitioner's assessment with FGD technique. Furthermore, empirical validity and the goodness of fit measurement model was measured with Confirmatory Factor Analysis (CFA) through the application of Lisrel 8.30 program. However, try out of test and implementation involves students of grade five and six elementary schools. The results of this research: (1) the instrument can be used to gathering data of developmental needs as based of guidance curriculum arrangement and to conduct program evaluation in elementary school, and (2) there are several items of student's developmental needs that needs to be fullfiled through classical guidance services.
\end{abstract}

Key words: needs assessment instrument, guidance curriculum, program evaluation instrument of guidance and counseling 


\section{Pendahuluan}

Idealnya, upaya untuk mencapai tujuan-tujuan pelayanan Bimbingan dan Konseling di Sekolah Dasar (BK di SD) tergambar dalam suatu rangkaian kegiatan yang tersusun secara sistematis, terstruktur, dan tertulis dalam suatu program yang pelaksanaannya berorientasi pada pemenuhan kebutuhan-kebutuhan dan pencapaian kompetensi-kompetensi perkembangan sesuai dengan tugas-tugas perkembangan peserta didik SD. Oleh sebab itu, perencanaan program, penyusunan kurikulum bimbingan, perumusan tujuan, penetapan kriteria keberhasilan pelayanan, pelaksanaan evaluasi program, dan pertanggungjawaban akuntabilitas pelayanan BK di SD harus diletakkan pada terpenuhinya kebutuhan-kebutuhan perkembangan yang melandasi pencapaian kompetensi-kompetensi dalam aktualisasi tugas perkembangan peserta didik SD yang menjadi target layanan program tersebut. Untuk itu, dibutuhkan instrumen asesmen kebutuhan yang reliabel dan valid sehingga dapat digunakan sebagai sarana pemasok data yang akurat dalam pengembangan kurikulum bimbingan dan evaluasi program BK di SD.

Pelayanan BK Perkembangan harus diletakkan dalam perspektif pemikiran sebagai upaya konkrit yang bersinergis dengan aktivitas pembelajaran di kelas menuju tercapainya proses dan hasil belajar yang lebih efektif. Dalam konteks itu, efektivitas belajar pembelajaran sangat ditentukan oleh ada tidaknya kepeduliaan guru terhadap pemenuhan kesejahteraan para peserta didiknya sebagaimana dapat ditunjukkan dengan memperhatikan kebutuhan-kebutuhan peserta didik. "The effectiveness of any teaching strategy or behavior change approach is influenced by the degree to which it responds to students "needs" (Jones \& Jones, 1998: 38).

Sekolah yang kurang peduli terhadap pemenuhan kesejahteraan para peserta didik akan mengakibatkan peserta didik merasa kurang mendapat tempat dan tidak dihargai, bahkan kehilangan martabat. Hargreaves (1982) mengemukakan bahwa sekolah sering sekali tidak mempedulikan atau kurang merawat para peserta didik yang martabat atau harga dirinya rendah, sehingga para peserta didik seperti itu sering kali menolak proses sekolah dan akhirnya beberapa meninggalkan sekolah atau drop out. 
Selain butuh belajar membaca, menulis, matematika, dan sains, para peserta didik juga perlu diajari keterampilan psikososial, kemahiran berolah diri, dan keterampilan kerja. Visi dan misi muatan Pengembangan Diri dalam KTSP (Permendiknas No. 22 Tahun 2006) agaknya berkehendak mendaratkan kebutuhan-kebutuhan non akademik semacam itu. Guru kelas di SD ditugasi untuk merencanakan, melaksanakan, dan mengevaluasi program bimbingan bermuatan materi-materi pengembangan diri yang dibutuhkan para peserta didik. Ketersediaan instrumen asesmen kebutuhan perkembangan murid SD dapat membantu guru kelas dalam melaksanakan tugas tersebut.

Erat kaitannya dengan pengembangan program BK di sekolah, Erford (2007: 132) mengelaborasi konsep Abraham Maslow yang menggambarkan urutan secara hirarkis kebutuhan-kebutuhan peserta didik sebagai berikut:

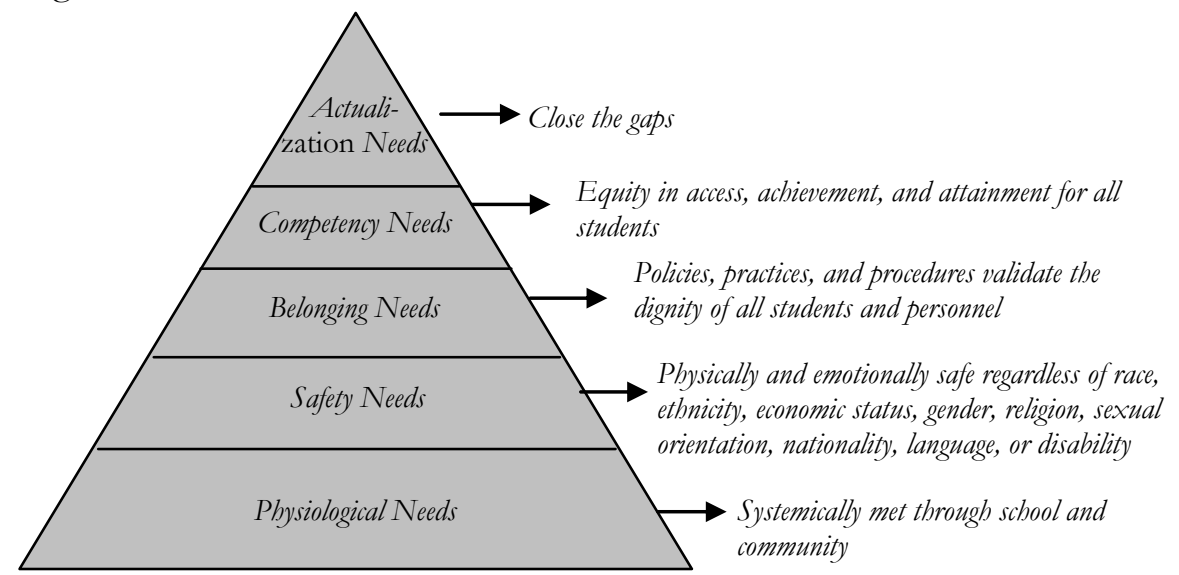

Gambar1. Maslow's hierarchy in a new vision school. All needs are met for all students

Dari hirarki kebutuhan tersebut terlihat bahwa kebutuhan berprestasi (sukses belajar) di sekolah (level 4) secara logis dimungkinkan tercapai apabila kebutuhan-kebutuhan fisik, rasa aman, dan rasa memiliki/diterima terpenuhi terlebih dahulu. Oleh sebab itu, Maslow (Brown \& Trusty, 2005) menyarankan bahwa agar peserta didik memiliki energi untuk belajar, maka 
kebutuhan-kebutuhan personal dasar mereka harus dipenuhi. Terpenuhinya kebutuhan-kebutuhan dasar, seperti rasa aman, rasa memiliki, rasa dicintai, rasa dihormati, dan rasa diri berharga akan memotivasi individu untuk mencapai meta-needs, yaitu kebutuhan berprestasi (berolah pikir, berilmu pengetahuan, mengejar kebaikan-kebaikan, keadilan, keindahan, keteraturan, dan keseimbangan) dan beraktualisasi diri.

Pemenuhan kebutuhan dasar (basic needs) peserta didik pada dasarnya adalah menjadi tanggung jawab keluarga, namun pemenuhan sebagian besar kebutuhan psikologis dan meta-needs peserta didik merupakan tugas sekolah yang disalurkan melalui fungsi pelayanan bimbingan dan konseling. Apabila guru dapat mengenali dan memenuhi kebutuhan sosial-personal para peserta didiknya, maka semakin terbuka jalan yang lebar bagi peserta didik untuk mengukir prestasi belajar yang cemerlang. Seperti ditegaskan, "It appears that having personal needs met enhances academic achievement and prosocial behavior while failure to have these needs met is associated with a myriad of academic and behavioral problems" (Dishion, French, \& Patterson, dalam Jones \& Jones, 1998: 42). Dari pandangan ini juga dapat dipahami bahwa kegagalan akademik dan munculnya berbagai masalah perilaku peserta didik adalah konsekuensi dari tidak terpenuhinya kebutuhan-kebutuhan sosial-personal mereka.

Dalam rangka mendesain dan mengelola program BK Perkembangan yang komprehensif yang berorientasi pada pencapaian kompetensi dan pemenuhan kebutuhan perkembangan peserta didik, Brown \& Trusty (2005) menyarankan bahwa rumusan tujuan-tujuan pelayanan BK harus didasarkan pada hasil analisis kebutuhan perkembangan peserta didik. Fokus analisis kebutuhan perkembangan peserta didik terletak pada jabaran dari kebutuhan-kebutuhan yang memfasilitasi berlangsung dan tercapainya tugas-tugas perkembangan mereka. Oleh sebab itu, Myrick (Brown \& Trusty, 2005: 126) menyebut tugas-tugas perkembangan (developmental tasks) sebagai kebutuhan-kebutuhan perkembangan (developmental needs), yang secara tradisional telah dijadikan sebagai dasar penyusunan pelayanan BK pada banyak sekolah. Artinya, secara eksplisit pelayanan BK di sekolah harus diorientasikan untuk memenuhi kebutuhan-kebutuhan perkembangan peserta didik. Dalam mendesain program bimbingan perkembangan, 
banyak ahli mendukung penggunaan tugas-tugas perkembangan sebagai panduan dalam mengidentifikasi kebutuhan-kebutuhan peserta didik (Sink, 2005: 191).

Secara khusus, Brown \& Trusty (2005: 129-130) mendeskripsikan kebutuhan-kebutuhan perkembangan yang menjadi muatan pelayanan BK di SD (elementary school years) meliputi kebutuhan-kebutuhan untuk memperlancar pelaksanaan tugas perkembangan sebagai berikut:

a. Mengembangkan konsep diri:

1) pemahaman diri sendiri: kesadaran menyangkut kelebihan-kelebihan, kelemahan-kelemahan, minat-minat, gambaran tubuh, perbedaanperbedaan, dan kesamaan-kesamaan dengan orang lain.

2) penghargaan terhadap diri sendiri, pandangan positif tentang diri sendiri, penerimaan diri.

3) mengembangkan rasa percaya diri, berani tampil, berlatih mengungkapkan gagasan sendiri.

b. Belajar membangun hubungan dengan teman sebaya dan belajar sabar:

1) keterampilan berkomunikasi.

2) keterampilan bergaul.

3) keterampilan mengelola rasa takut.

4) keterampilan untuk menolak dan ketegasan.

5) keterampilan bekerjasama.

c. Mengembangkan toleransi terhadap orang lain dan sikap-sikap positif terhadap kelompok:

1) kesadaran terhadap perbedaan dan menghargai perbedaan.

2) toleransi terhadap perbedaan budaya, suku, ras, agama.

3) menghargai dan menghormati pendapat/gagasan orang lain.

d. Belajar bersikap/berperilaku sesuai dengan peran jenis (sex role):

1) mempelajari peran sosial sebagai laki-laki atau perempuan sesuai harapan masyarakat.

2) mengenal berbagai macam pilihan karir bagi laki-laki dan perempuan.

3) mengetahui perkembangan seksualitas seumurnya dan berperilaku sehat terhadap seksnya. 
e. Mengembangkan keterampilan-keterampilan dasar bersekolah/akademik:

1) berkemampuan membaca, menulis, berhitung sesuai dengan tuntutan kurikulum.

2) keterampilan mendengarkan (listening).

3) keterampilan mengikuti petunjuk/instruksi.

4) keterampilan mengorganisasi aktivitas belajar, tugas-tugas sekolah, kegiatan lainnya.

5) keterampilan belajar (study skills) yang efektif.

6) keterampilan menghadapi ulangan-ulangan/tes.

f. Mengembangkan keterampilan-keterampilan yang perlu dalam kehidupan sehari-hari:

1) berlatih dan membiasakan diri dalam melakukan pekerjaan seharihari.

2) belajar menghargai makna bekerja, mengelola waktu, hidup hemat dan produktif.

3) berlatih mengambil keputusan-keputusan sederhana.

4) belajar berperilaku dan mengembangkan kebiasaan pola hidup sehat dan efektif.

g. Mengembangkan kata hati, moralitas, dan nilai-nilai sebagai pedoman berperilaku:

1) membiasakan bersikap dan berperilaku jujur, santun, rendah hati, mentaati norma-norma.

2) memahami dan mampu mengenali perilaku baik dan buruk, perbuatan salah dan benar.

3) berlatih mengembangkan perilaku bertanggung jawab dan konsekuen.

h. Belajar mengembangkan pribadi mandiri:

1) berlatih mengatur dan mengelola keperluan diri sendiri, perawatan diri, kegiatan pribadi.

2) belajar menyusun dan melaksanakan rencana, pilihan-pilihan, prioritas-prioritas sendiri. 
3) mengembangkan daya tahan terhadap tekanan-tekanan kelompok sebaya.

Kebutuhan-kebutuhan perkembangan seperti terurai di atas harus digali dan dirumuskan menjadi tujuan-tujuan dan muatan pelayanan BK di SD yang terklasifikasi dalam empat bidang bimbingan, yaitu (1) bimbingan pribadi; (2) bimbingan sosial; (3) bimbingan belajar; dan (4) bimbingan karir; yang penyajiannya dapat dilakukan melalui layanan bimbingan kelompok/klasikal, konseling kelompok, konseling individual, layanan orientasi dan pemberian informasi, layanan konsultasi, dan layanan penunjang lainnya (Puskur Depdiknas, 2006). Karena pelayanan BK Perkembangan lebih bersifat proaktif, preventif, dan developmental, maka idealnya setiap kelas mendapat kesempatan khusus untuk jam-jam pelayanan semacam itu, sehingga secara sistematis seluruh peserta didik terlayani untuk mendapat bantuan dalam memperlancar aktualisasi dan pencapaian tugas perkembangannya. Selaras dengan hal tersebut, penelitian ini bertujuan untuk menghasilkan instrumen asesmen untuk mengungkap kebutuhan peserta didik yang selanjutnya disebut Invantori Kebutuhan Perkembangan Murid (IKPM) sebagai landasan menyusun kurikulum bimbingan dan alat ukur evaluasi program bimbingan klasikal di sekolah dasar.

\section{Metode Penelitian}

Desain pengembangan dalam penelitian ini mengikuti model Plomp (1999) yang mendeskripsikan tahapan siklus R \& D dalam lima tahapan, yaitu (1) fase investigasi awal; (2) fase desain; (3) fase realisasi/konstruksi; (4) fase tes, evaluasi, dan revisi; dan (5) fase implementasi. Kelima fase tersebut dilukiskan dalam bentuk skema sebagai berikut: 


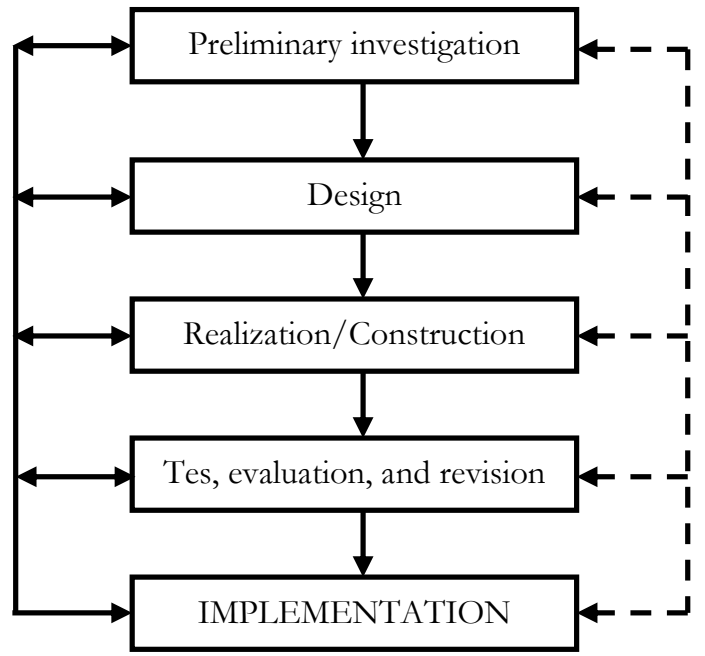

Gambar 2. Skema Model Pengembangan Menurut Plomp (1999)

Untuk memvalidasi produk instrumen yang dikembangkan dalam penelitian ini ditempuh strategi experts judgment dengan teknik delphi (Linstone \& Turoff, 2002) yang dilanjutkan dengan penjajakan uji kelayakterapan oleh pengguna melalui teknik focus group discussion (Dean, 1994), yang melibatkan 60 orang praktisi, yaitu guru BK, kepala sekolah dasar, konselor SD, guru kelas SD. Brinkerhoff, et al. (1986: 101) menyarankan, "Use of self-ratings in a workshop, however, as a means for partisipants to select paths of study, would be far more valid". Data ratings tersebut diolah untuk dibandingkan atau dikorelasikan antarjudges/ekspert atau antarkelompok eksperts atau antarkelompok users/partisipan (Sugiyono, 2008). Tingkat kesepahaman/konsensus antarahli (reliabilitas) terhadap penilaian-penilaian yang mereka berikan, dianalisis dengan teknik statistik Cohen's Kappa (к), dan nilai kriteria minimal, yaitu 0,70 (Linn, 1989: 106). Sebelum penilaian diberikan, kepada penilai telah dipersiapkan dan diberikan: (1) panduan penilaian instrumen oleh ekspert/praktisi, (2) ringkasan konsep dan konstruk instrumen IKPM, dan (3) instrumen IKPM. 
Validitas internal instrumen yang diperiksa meliputi validitas isi dan konstruk (Nurgiyantoro, Gunawan, \& Marzuki, 2000; Sugiyono 2008) yang mencerminkan telaah rasional mengenai kesesuaian muatan/isi instrumen dengan materi yang seharusnya akan diukur (telaah kisi-kisi) dan logical construct (Mardapi, 2008) dijajaki dengan cara mengeksplorasi pertimbangan pakar dan pengguna (AERA-APA, 1999: 11-13; Standards 1.1; 1.3; 1.7). Hal-hal yang dipertimbangkan secara rasional oleh ahli menyangkut isi dan kualitas konstruk instrumen meliputi: kesesuaian konstruk dan perumusan item/items dengan konsep teori yang mendukung, kesesuaian dan ketercukupan isi dengan tuntutan kisi-kisi yang direncanakan, kejelasan petunjuk, cakupan/keluasan aspek konstruk instrumen, kejelasan indikator, kejelasan rumusan item, kecocokan/ketepatan/kepadanan antara indikator dengan item, proporsi dan kecukupan jumlah item, kesederhanaan (simplicity) rumusan/pengkalimatan item, kemudahan pemaknaan, tingkat ambiguitas item, tingkat keterbacaan, standar notasi/format huruf dan layout, kemudahan cara menjawab, ketaatan asas berbahasa Indonesia yang baik, benar, dan santun; menghindarkan responden dari "pengarahan terselubung", tekanan, dan rasa malu dalam menjawab; efisiensi waktu/ tenaga pengerjaan, efisiensi biaya, dan praktikabilitas pengadministrasian.

Informasi mengenai reliabilitas instrumen perlu diketahui lebih dahulu sebelum dilanjutkan dengan estimasi validitas, sebab terhadap instrumen yang tidak reliabel tiada manfaat menyelidiki validitasnya. Reliabilitas (konsistensi internal) instrumen IKPM yang dikembangkan melalui penelitian ini diuji dengan teknik Alpha Cronbach. Teknik ini dipilih karena cocok dipergunakan untuk menguji reliabilitas instrumen yang memuat pertanyaan/pernyataan yang jawabannya berskala (Nurgiyantoro, Gunawan, \& Marzuki, 2000: 309). Selain itu, tidak cukup alasan untuk menganggap bahwa varians belahan skor (gasal-genap) instrumen sungguh-sungguh sama/paralel, maka estimasi keseluruhan alat ukur dapat diperoleh dengan menggunakan koefisien alpha (Cronbach, dalam Mardapi, 2008: 42).

Validitas konstruk empiris instrumen IKPM diuji dengan pendekatan confirmatory factor analysis dengan teknik Lisrel (Joreskog \& Sorbom, 1993). Teknik ini dipakai untuk melihat indeks validitas konstruk dan sekaligus 
menguji kecocokan (fit) model pengukuran (measurement model), yaitu kecocokan model pengukuran antara konsep model teoritis dengan data empiris. Penentuan kecocokan model pengukuran didasarkan pada tiga kriteria: yaitu: 1) Significance Probability; 2) Root Mean Square Error of Approximation (RMSEA); dan 3) Normed Fit Index (NFI), sedangkan penentuan valid tidaknya butir instrumen diketahui dari hasil hitung factor loading (muatan faktor) yang lebih besar atau sama dengan 0,30 atau diperiksa dengan mengamati diagram path yang dihasilkan dalam proses analisis. Indeks item berwarna merah pada diagram path (di layar monitor) mengindikasikan bahwa item tersebut tidak valid (Djemari Mardapi, dalam latihan praktikum cfa), jika memungkinkan dapat direvisi, atau dibuang.

Subjek penelitian (untuk ujicoba instrumen dan implementasi) terdiri dari para siswa kelas V dan VI dari beberapa SD sebagai berikut:

Tabel 1. Subjek Penelitian

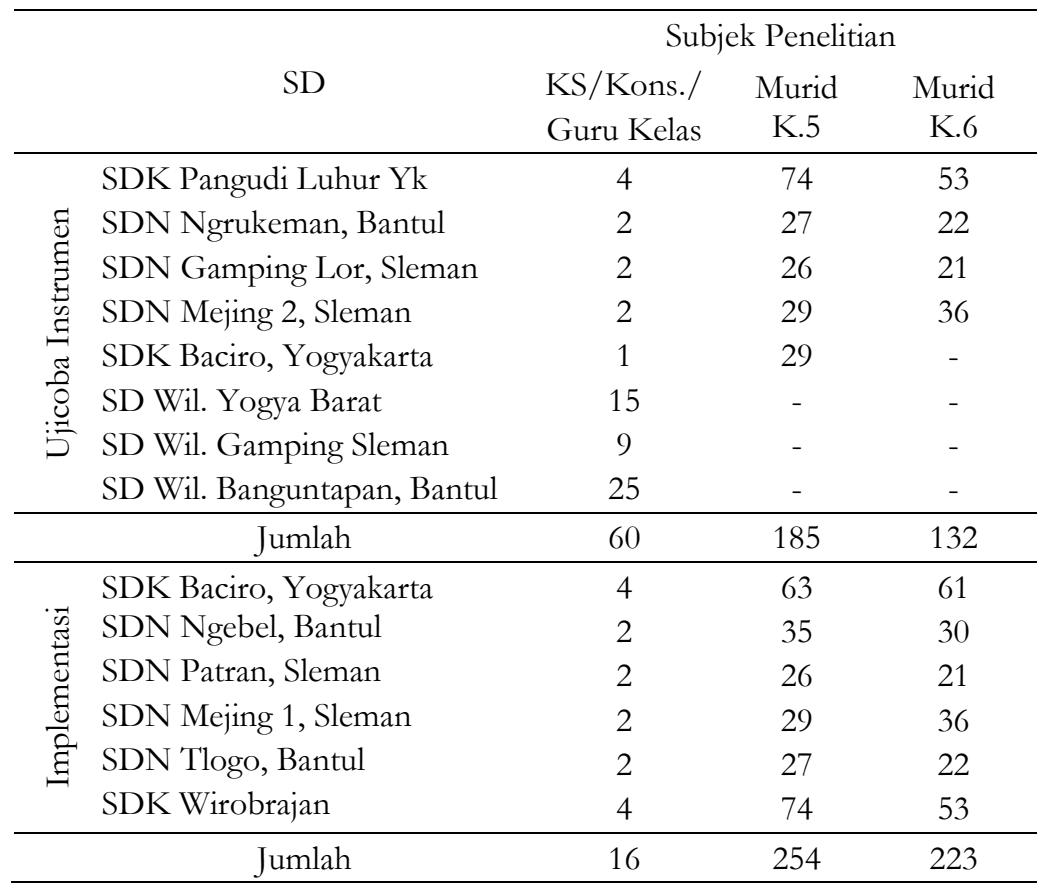




\section{Hasil Penelitian dan Pembahasan}

Dengan mengikuti prosedur pengembangan model Plomp (1999), tahap investigasi awal dipusatkan pada kajian konseptual pengembangan instrumen asesmen kebutuhan berdasarkan konsep Brown \& Trusty (2005: 129-130) sebagaimana dipaparkan pada bagian pendahuluan. Pengkajian konseptual dilanjutkan dengan tahap desain yang menghasilkan konstruk instrumen sebagai berikut:

Tabel 2. Kisi-kisi Inventori Kebutuhan-kebutuhan Perkembangan Murid (IKPM) Responden: Peserta Didik Kelas IV - VI SD

\begin{tabular}{|c|c|c|}
\hline ASPEK & INDIKATOR & $\begin{array}{l}\text { No. } \\
\text { item }\end{array}$ \\
\hline \multirow[t]{3}{*}{$\begin{array}{l}\text { 1. Kebutuhan } \\
\text { untuk me- } \\
\text { ngembangkan } \\
\text { konsep diri }\end{array}$} & $\begin{array}{l}\text { 1. Kebutuhan untuk memahami diri sendiri, menyangkut: } \\
\text { kelebihan, kelemahan, minat, gambaran tubuh, } \\
\text { perbedaan-perbedaan, dan kesamaan-kesamaan dengan } \\
\text { orang lain. }\end{array}$ & $1-6$ \\
\hline & $\begin{array}{l}\text { 2. Kebutuhan untuk menghargai diri sendiri, pandangan } \\
\text { positif tentang diri sendiri, penerimaan diri. }\end{array}$ & $7-9$ \\
\hline & $\begin{array}{l}\text { 3. Kebutuhan untuk mengembangkan rasa percaya diri, } \\
\text { berani tampil, berlatih mengungkapkan gagasan sendiri }\end{array}$ & $10-12$ \\
\hline $\begin{array}{l}\text { 2. Kebutuhan } \\
\text { untuk belajar } \\
\text { membangun } \\
\text { hubungan } \\
\text { dengan teman }\end{array}$ & $\begin{array}{l}\text { 1. Kebutuhan-kebutuhan unt mengembangkan berbagai } \\
\text { keterampilan: berkomunikasi dengan teman sebaya, } \\
\text { bergaul dengan teman sejenis atau lawan jenis, } \\
\text { mengelola rasa takut, menghargai/solider thd teman, } \\
\text { berani menolak dan ketegasan (assertif), bekerjasama. }\end{array}$ & $13-19$ \\
\hline $\begin{array}{l}\text { sebaya dan } \\
\text { belajar sabar: }\end{array}$ & $\begin{array}{l}\text { 2. Kebutuhan untuk memahami perbedaan, mengelola } \\
\text { konflik, pengendalian diri, dan bersabar terhadap } \\
\text { teman. }\end{array}$ & $20-23$ \\
\hline $\begin{array}{l}\text { 3. Kebutuhan } \\
\text { unt belajar } \\
\text { bersikap/ }\end{array}$ & $\begin{array}{l}\text { 1. Kebutuhan unt belajar menerima } \\
\text { keadaan/keterbatasan fisik sebagai anak laki-laki atau } \\
\text { perempuan sesuai jenis kelamin. }\end{array}$ & $24-25$ \\
\hline $\begin{array}{l}\text { berperilaku } \\
\text { sesuai dengan }\end{array}$ & $\begin{array}{l}\text { 2. Berperan/berperilaku sebagai laki-laki atau perempuan } \\
\text { sesuai tuntutan kelompok sebayanya. }\end{array}$ & $26-27$ \\
\hline $\begin{array}{l}\text { peran jenis }(\text { sex } \\
\text { role): }\end{array}$ & $\begin{array}{l}\text { 3. Mengetahui perkembangan seksualitas seumurnya, } \\
\text { bersikap positif terhadap teman sejenis maupun lawan } \\
\text { jenis, dan berperilaku sehat terhdp seksnya. }\end{array}$ & $28-30$ \\
\hline
\end{tabular}




\begin{tabular}{|c|c|c|}
\hline ASPEK & INDIKATOR & $\begin{array}{l}\text { No. } \\
\text { item }\end{array}$ \\
\hline $\begin{array}{l}\text { 4. Kebutuhan } \\
\text { untuk me- } \\
\text { ngembangkan } \\
\text { keterampilan- } \\
\text { keterampilan } \\
\text { dasar berseko- } \\
\text { lah/akademik: }\end{array}$ & $\begin{array}{l}\text { 1. Kebutuhan untuk mengembangkan kemampuan/ } \\
\text { keterampilan membaca, menulis, berhitung dengan } \\
\text { cepat, mendengarkan (listening), mengikuti } \\
\text { petunjuk/instruksi, mengorganisasi aktivitas belajar, } \\
\text { tugas-tugas sekolah, kegiatan lainnya secara seimbang, } \\
\text { mengelola sikap/cara belajar (study skills) yang efektif, } \\
\text { menghadapi ulangan-ulangan/tes. }\end{array}$ & $31-38$ \\
\hline & $\begin{array}{l}\text { 2. Kebutuhan untuk memperoleh informasi \& } \\
\text { perencanaan studi lanjut. }\end{array}$ & $39-40$ \\
\hline $\begin{array}{l}\text { 5. Kebutuhan } \\
\text { untuk me- } \\
\text { ngembangkan } \\
\text { berbagai } \\
\text { keterampilan }\end{array}$ & $\begin{array}{l}\text { 1. Kebutuhan unt berlatih dan membiasakan diri dalam: } \\
\text { melakukan pekerjaan sehari-hari, menghargai makna } \\
\text { bekerja, mengelola waktu, hidup hemat dan produktif, } \\
\text { mengambil keputusan-keputusan sederhana, } \\
\text { berperilaku \& mengembangkan kebiasaan hidup sehat. }\end{array}$ & $41-46$ \\
\hline $\begin{array}{l}\text { hidup sehari- } \\
\text { hari, belajar } \\
\text { menjadi } \\
\text { pribadi } \\
\text { mandiri, dan } \\
\text { mengembang- }\end{array}$ & $\begin{array}{l}\text { 2. Kebutuhan untuk belajar/berlatih: mengatur \& } \\
\text { mengelola keperluan diri sendiri, perawatan diri, } \\
\text { kegiatan pribadi; menyusun dan melaksanakan rencana, } \\
\text { pilihan-pilihan, prioritas-prioritas sendiri; } \\
\text { mengembangkan daya tahan thd tekanan-tekanan } \\
\text { kelompok sebaya. }\end{array}$ & $47-51$ \\
\hline $\begin{array}{l}\text { kan kata hati, } \\
\text { moralitas, } \\
\text { nilai-nilai: }\end{array}$ & $\begin{array}{l}\text { 3. Kebutuhan untuk: mengembangkan sikap/perilaku } \\
\text { rajin beriman, beribadah, bertaqwa, dan beramal; } \\
\text { membiasakan bersikap dan berperilaku jujur, santun, } \\
\text { rendah hati, mentaati norma-norma; memahami dan } \\
\text { mampu mengenali perilaku baik dan buruk, perbuatan } \\
\text { salah dan benar; berlatih mengembangkan perilaku } \\
\text { bertanggung jawab dan konsekuen. }\end{array}$ & $52-60$ \\
\hline
\end{tabular}

Berdasarkan konstruk instrumen yang telah dirancang, prosedur pengembangan dilanjutkan pada tahap realisasi/konstruksi. Pada tahap ini, butir-butir instrumen mulai disusun dengan berpedoman pada indikator yang dikonstruk pada setiap aspek. Terdapat 60 butir instrumen IKPM dengan skala penilaian Amat Butuh (skor 4); Butuh (skor 3); Sedikit Butuh (skor 2); dan Kurang Butuh (skor 1).

Draft awal instrumen dimintakan telaah tiga orang pakar dalam bidang keahlian bimbingan dan konseling, evaluasi, dan psikologi untuk memeriksa keterpenuhan validitas isi dan validitas konstruk-logis ins- 
trumen. Simultan dengan itu, ditempuh cara FGD (2 tahap) dengan melibatkan 60 orang guru kelas, kepala sekolah, dan konselor SD. Data penilaian pakar dan pengguna terhadap kualitas instrumen terekam sebagai berikut:

Tabel 3.Data Penilaian Ekspert dan Pengguna terhadap Kualitas Konstruk Instrumen IKPM

(Penilaian dilakukan oleh 3 orang ahli dan 60 orang Guru SD)

\begin{tabular}{clllllllllcc}
\hline No & Aspek Kualitas Konstruk Instrumen & \multicolumn{1}{c}{ Penilaian Ahli } & \multicolumn{5}{c}{ Penilaian Pengguna (FGD) } \\
\hline 1 & Kejelasan petunjuk pengisian instrumen & 4 & 4 & 3 & 11 & 3,67 & 4,71 & 4,90 & 4,81 & Baik \\
2 & Keluasan cakupan aspek konstruk & 5 & 5 & 5 & 15 & 5,00 & 4,29 & 4,67 & 4,48 & Sangt baik \\
& instrumen & & & & & & & & & \\
3 & Kejelasan indikator setiap aspek & 4 & 4 & 4 & 12 & 4,00 & 4,43 & 4,52 & 4,48 & Baik \\
4 & Kejelasan rumusan item & 4 & 4 & 4 & 12 & 4,00 & 4,36 & 4,62 & 4,49 & Baik \\
5 & Kecocokan indikator dengan item & 4 & 4 & 4 & 12 & 4,00 & 4,57 & 4,81 & 4,69 & Baik \\
6 & Proporsi dan kecukupan jumlah item & 5 & 4 & 5 & 14 & 4,67 & 4,36 & 4,52 & 4,44 & Sangt baik \\
7 & Kesederhanaan (simplicity) rumusan item & 4 & 4 & 4 & 12 & 4,00 & 4,57 & 4,71 & 4,64 & Baik \\
8 & Kemudahan pemaknaan/memahami item & 4 & 4 & 3 & 11 & 3,67 & 4,29 & 4,43 & 4,36 & Baik \\
9 & Keterbacaan/kemudahan dalam membaca & 4 & 4 & 4 & 12 & 4,00 & 4,50 & 4,62 & 4,56 & Baik \\
10 & Standar notasi/format huruf dan layout & 5 & 4 & 4 & 13 & 4,33 & 4,36 & 4,62 & 4,49 & Sangt baik \\
11 & Kemudahan cara menjawab & 4 & 4 & 4 & 12 & 4,00 & 4,50 & 4,76 & 4,63 & Baik \\
12 & Efisiensi waktu/tenaga dalam mengerjakan & 4 & 4 & 4 & 12 & 4,00 & 4,29 & 4,57 & 4,43 & Baik \\
13 & Penggunaan bahasa Indonesia yang baku & 4 & 4 & 4 & 12 & 4,00 & 4,57 & 4,81 & 4,69 & Baik \\
14 & Menghindarkan responden dari & 4 & 4 & 4 & 12 & 4,00 & 4,43 & 4,52 & 4,48 & Baik \\
& "pengarahan terselubung", tekanan, malu \\
dlm menjawab & & & & & & & & & \\
\hline
\end{tabular}

Keterangan: Skala 1 - 5; Bobot Nilai Keputusan: (3 X Skor Ahli +1 X Skor Pengguna): 4

\begin{tabular}{ccc}
\hline$>4,2$ & Sangat Baik & Dapat dijadikan contoh \\
$3,41-4,20$ & Baik & Dapat digunakan tanpa perbaikan \\
$2,61-3,40$ & Cukup & Dapat digunakan dengan sedikit perbaikan \\
$1,81-2,60$ & Buruk & Belum dapat digunakan, masih perlu banyak \\
$\leq 1,8$ & Sangat Buruk & perbaikan \\
\hline
\end{tabular}


Fakta pada tabel menunjukkan bahwa rerata skor penilaian pakar terhadap kualitas konstruk instrumen IKPM relatif lebih rendah dibandingkan dengan rerata skor penilaian praktisi/pengguna. Hal ini dimungkinkan terjadi karena penilaian para pakar dilakukan terhadap draft awal instrumen (belum mengalami revisi), dengan kecermatan tinggi, dan dengan penuh kehati-hatian; sedangkan penilaian para pengguna melalui FGD dilakukan setelah instrumen mengalami revisi berdasarkan masukan dari ketiga pakar dan sebelum menilai, pengguna terlebih dahulu dibawa ke dalam situasi diskusi kelompok (FGD) guna memahami konteks secara lebih leluasa, serta selalu mendapat penjelasan dari peneliti/pengembang. Perbedaan tersebut menjadi semakin nyata apabila dibandingkan antara rerata skor penilaian pakar dengan rerata skor pengguna pada FGD tahap ke-2 yang pelaksanaannya dilakukan pada jarak waktu satu bulan kemudian.

Reliabilitas penilaian (tingkat kesepakatan) antarpenilai (inter-rater reliability) terhadap hasil penilaian kualitas konstruk instrumen IKPM diestimasi dengan koefisien Cohen's Kappa (к), dalam mana batas bawah koefisien reliabilitas yang digunakan untuk menetapkan tingkat reliabilitas hasil penilaian antarpenilai adalah 0,70 (Linn, 1989: 106).

Tabel 4. Rekapitulasi Hasil Analisis Koefisien Kappa Penilaian antarketiga Ahli terhadap Kualitas Konstruk Instrumen IKPM

\begin{tabular}{lcc}
\hline \multicolumn{1}{c}{ Instrumen } & Antarpenilai & Value of Agreement $(\kappa)$ \\
\hline Inventori Kebutuhan & $1 \& 2$ & 1,000 \\
Perkembangan Murid & $1 \& 3$ & 0,854 \\
(IKPM) & $2 \& 3$ & 0,854 \\
\hline
\end{tabular}

Hasil perhitungan menunjukkan bahwa penilaian antarketiga ahli terhadap kualitas konstruk instrumen sangat reliabel. Demikian pula, pada penilaian pengguna tampak terdapat perkembangan nilai yang semakin membaik antara penilaian pada FGD tahap pertama dan kedua. Dengan memberikan pembobotan yang berbeda, yaitu penilaian pakar dihargai tiga kali lebih besar dari penilaian pengguna, tampak bahwa secara konseptual (logical construct validity) pakar dan pengguna menilai kualitas konstruk instrumen IKPM sudah baik. 
Mencermati hasil analisis data penilaian praktisi/pengguna terhadap kualitas konstruk instrumen seperti pada tabel di atas, tampak pula adanya tren/kecenderungan peningkatan nilai rata-rata dari penilaian praktisi/ pengguna pada FGD tahap 1 dan 2. Tren perkembangan nilai setiap aspek kualitas dan nilai rata-rata total antara hasil penilaian tahap 1 dan 2 dapat dipahami sebagai capaian nilai tambah yang dihasilkan dari upaya perbaikan aspek-aspek kualitas instrumen dari satu tahap ke tahap berikutnya. Tren perkembangan nilai kualitas konstruk instrumen IKPM dari data hasil penilaian praktisi tahap 1 ke tahap 2 dilukiskan pada grafik berikut ini:

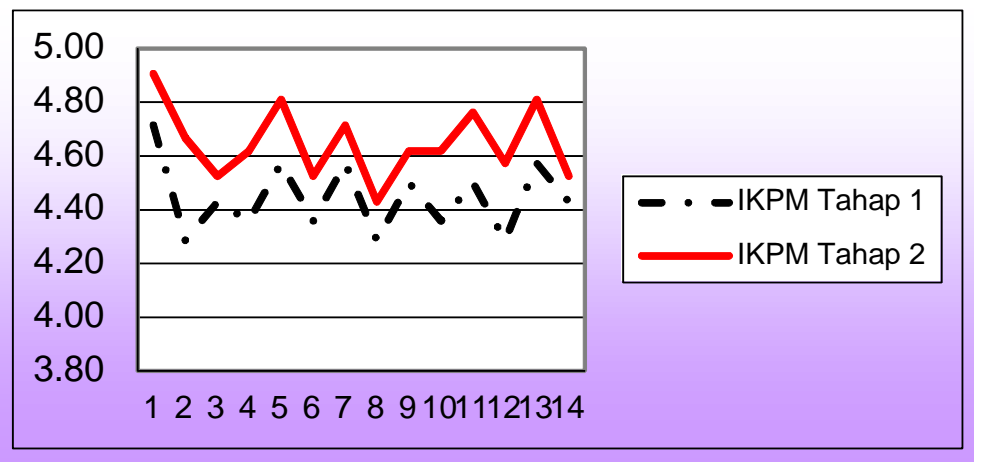

Gambar 3 Perkembangan Penilaian Calon Pengguna terhadap Kualitas Konstruk Instrumen IKPM

Analisis estimasi reliabilitas Alpha Cronbach terhadap instrumen IKPM dilakukan dengan aplikasi program SPSS for Windows. Rekapitulasi hasil analisis estimasi reliabilitas dilaporkan sebagai berikut:

Tabel 5. Hasil Analisis Estimasi Reliabilitas Instrumen IKPM

\begin{tabular}{clc}
\hline \multicolumn{1}{c}{ Tahap Pengujian } & \multicolumn{1}{c}{ Indeks Reliabilitas } & \multicolumn{1}{c}{ Klasifikasi } \\
\hline Tahap Ujicoba & $\begin{array}{l}0,9074(\mathrm{~N}=40) ; 0,9181 \\
(\mathrm{~N}=317)\end{array}$ & sangat tinggi \\
Tahap Implementasi & $\begin{array}{l}0,9732(\mathrm{~N}=40) ; 0,9592 \\
(\mathrm{~N}=477)\end{array}$ & sangat tinggi \\
\hline
\end{tabular}


Data tabel menunjukkan reliabilitas instrumen IKPM yang diujikembangkan memiliki indeks reliabilitas Alpha $>0,90$; baik yang diuji dengan cuplikan sampel kecil $(\mathrm{N}=40)$ maupun diuji dengan keseluruhan sampel pada tahap ujicoba dan tahap implementasi.

Kecocokan model pengukuran dan membuktikan validitas konstruk instrumen IKPM dilakukan dengan analisis faktor konfirmatori (CFA) dengan bantuan program Lisrel 8.51 (Joreskog \& Sorbom, 1993). Tahap awal dalam melakukan analisis faktor konfirmatori adalah menguji kesesuaian (fit) model antara konsep teoritis dan data empirik. Model dikatakan sesuai antara konsep teoritis dengan data empirik jika memenuhi 3 (tiga) kriteria berikut, yaitu:

Tabel 6. Standar Kriteria Goodness of Fit Indices (GFI)

\begin{tabular}{lc}
\hline \multicolumn{1}{c}{ Goodness of Fit Indices } & Cut-of Value \\
\hline Significance Probability (p-value) & $\geq 0,05$ \\
Root Mean Square Error of Aproximation (RMSEA) & $<0,08$ \\
Normed Fit Index (NFI) & $>0,90$ \\
\hline Sumber: Joreskog \& Sorbom (dalam Solimun, 2002: 80)
\end{tabular}

Hasil analisis faktor konfirmatori ditampilkan dalam diagram path dalam bentuk standardized. Bentuk standardized diperlukan untuk melihat validitas suatu butir dalam arti bahwa suatu butir mengukur indikator jika memiliki factor loading (muatan faktor) lebih besar atau sama dengan 0,30, sebaliknya jika muatan faktor lebih kecil dari 0,30 maka butir tersebut tidak mengukur indikatornya (Solimun, 2002: 83).

Hasil analisis kecocokan model pengukuran dan validitas konstrukinstrumen IKPM pada aspek pertama dan kedua dengan program Lisrel 8.51 memvisualisasikan output standardized seperti disajikan pada Gambar 4. 


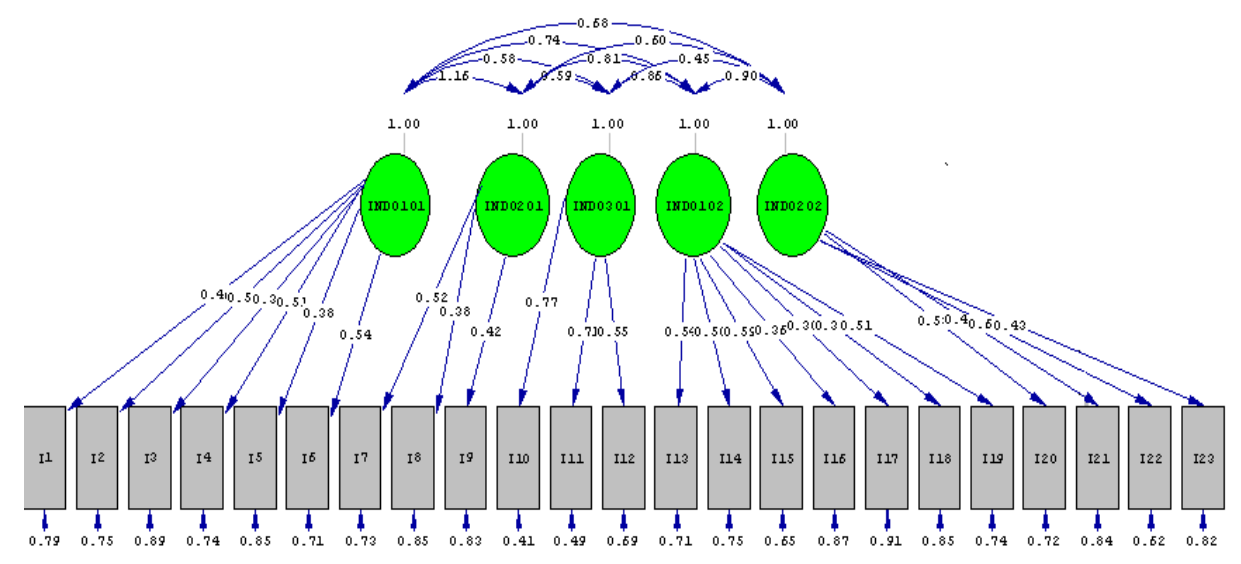

Chi-square=103.77, df=220, P-value=0.3172, RMSEA=0.074

Gambar 4. Standardized solution instrumen IKPM

Aspek I : Kebutuhan untuk mengembangkan konsep diri (1-12) dan

Aspek II : Kebutuhan untuk membangun relesi dengan teman sebaya dan belajar sabar (13-23)

Mencermati Gambar 4, tampak bahwa muatan faktor untuk semua item pada aspek pertama untuk ketiga indikator: IND0101, IND0201, dan IND0301 (item nomor 1 s.d. 12) dan aspek kedua untuk kedua indikator: IND0102 dan IND0202 (item nomor 13 s.d. 23) lebih besar dari kriteria yang digunakan yaitu 0,3 . Hal tersebut menunjukkan bahwa semua butir tersebut mengukur dan membangun masing-masing indikatornya.

Untuk aspek ketiga dan keempat IKPM, hasil analisis dengan program Lisrel 8.51 memvisualisasikan output standardized yang disajikan pada Gambar 5 berikut ini: 


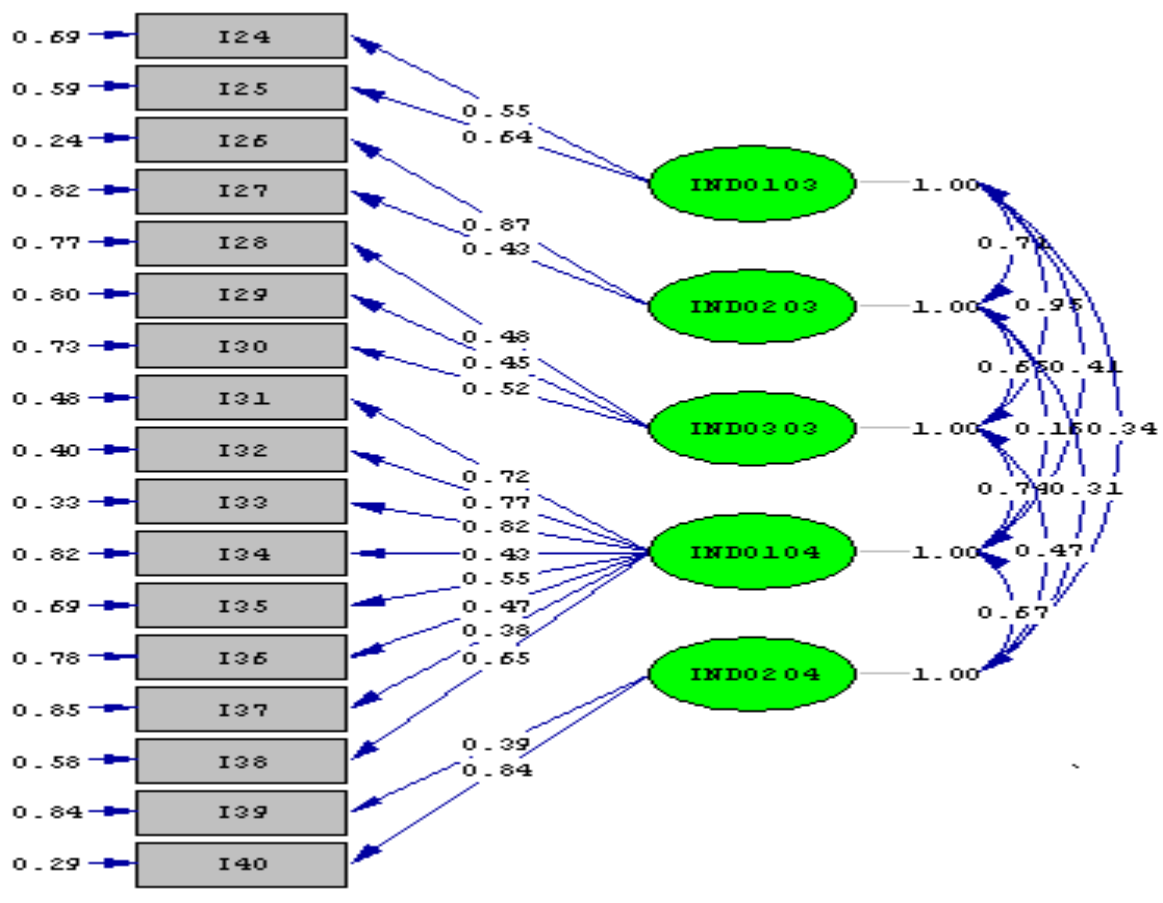

Chi-Square=154.96, df=109, P-value=0.71342, RMSEA=0.0101

Gambar 5. Penyelesaian yang Terstandarisari untuk Instrumen IKPM Aspek Ketiga dan Keempat

Aspek III : Kebutuhan untuk belajar bersikap/berperilaku sesuai dengan peran jenis (24-30).

Aspek IV : Kebutuhan untuk mengembangkan keterampilan-keterampilan dasar bersekolah/akademik (31-40).

Mencermati Gambar 5, tampak bahwa muatan faktor untuk semua item pada aspek ketiga untuk semua indikator, dengan item nomor 24 s.d. 30 dan aspek keempat untuk indikator pertama (IND0104) dan indikator kedua (IND0204), dengan item nomor 31 s.d. 40 lebih besar dari kriteria yang digunakan, yaitu 0,3 . Hal tersebut menunjukkan bahwa semua item tersebut mengukur dan membangun masing-masing indikator Dengan 
demikian, semua item tersebut secara empirik mengukur dan membangun semua indikator yang dikonstruk pada aspek ketiga IKPM secara signifikan. berikut:

Untuk aspek kelima dari instrumen IKPM, tergambar hasil analisis

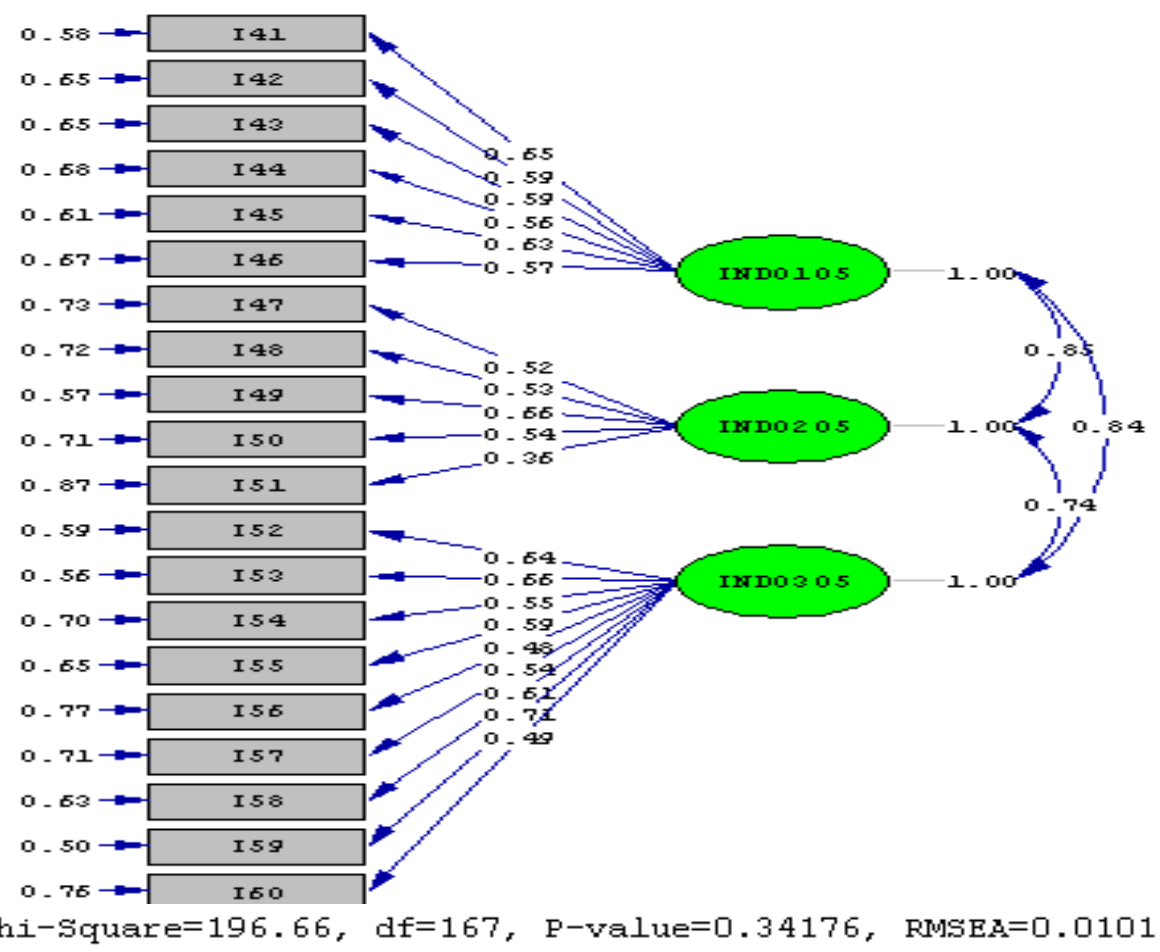

Gambar 6. Penyelesaian yang Terstandarisari untuk instrumen IKPM Aspek Kelima

Tampak pada Gambar 6 bahwa muatan faktor untuk semua item pada ketiga indikator lebih besar dari kriteria yang digunakan yaitu 0,3 . Hal tersebut menunjukkan bahwa semua item tersebut mengukur dan membangun masing-masing indikatornya, sehingga dapat disimpulkan bahwa 
semua butir untuk ketiga indikator yang dikonstruk pada aspek kelima instrumen IKPM mengukur indikator secara signifikan.

Mencermati rekam hasil hitung kecocokan model pengukuran pada ketiga diagram path di atas tampak bahwa untuk ketiganya hasil uji fit model telah memenuhi kriteria, yaitu p-values $\geq 0,05 ; R M S E A<0,08$; dan $N F I>0,90$, artinya terdapat kecocokan antara konsep teoritis dengan data empirik. Secara keseluruhan instrumen IKPM yang dikembangkan dalam penelitian ini, yang dikonstruk dalam 5 (lima) aspek dan dijabarkan dalam 13 indikator serta memuat 60 butir kebutuhan telah memenuhi syarat validitas konstruk dan dapat digunakan sebagai alat untuk mengukur intensitas kebutuhan perkembangan murid kelas 5 atau 6 SD sesuai dengan konstruk teoritisnya.

Tahap implementasi penggunaan instrumen IKPM pada 16 kelas SD menghasilkan data butir-butir kebutuhan perkembangan yang intens sebagai berikut:

Tabel 7. Identifikasi Butir KPM Peringkat 20 Terintens dalam Implikasinya terhadap Penyusunan Kurikulum Bimbingan Klasikal pada Enam SD

Tahun 2010

\begin{tabular}{|c|c|c|c|c|c|c|c|}
\hline $\begin{array}{l}\text { No } \\
\text { Butir }\end{array}$ & $\begin{array}{l}\text { AKU BUTUH BIMBINGAN AGAR DAPAT: } \\
\qquad \mathrm{N}=\end{array}$ & $\begin{array}{c}\text { Wiro- } \\
\text { brajan } \\
(127)\end{array}$ & $\begin{array}{l}\text { Me- } \\
\text { jing } \\
(71)\end{array}$ & $\begin{array}{l}\mathrm{Pa}- \\
\text { tran } \\
(47)\end{array}$ & $\begin{array}{c}\text { Tlo- } \\
\text { go } \\
(48)\end{array}$ & $\begin{array}{c}\text { Nge- } \\
\text { bel } \\
(65)\end{array}$ & $\begin{array}{c}\text { Baci- } \\
\text { ro } \\
(119)\end{array}$ \\
\hline 1. & $\begin{array}{l}\text { memahami kelebihan-kelebihanku/sifat-sifatku } \\
\text { yang positif }\end{array}$ & 1 & & & & & 3 \\
\hline 2. & $\begin{array}{l}\text { mengetahui kekurangan-kekurangan yang ada } \\
\text { dalam diriku }\end{array}$ & 3 & 14 & 7 & 2 & 3 & 9 \\
\hline 4. & $\begin{array}{l}\text { memahami keadaan/perubahan-perubahan } \\
\text { tubuhku }\end{array}$ & 17 & 34 & & 12 & 13 & 11 \\
\hline 6. & $\begin{array}{l}\text { menyadari perbedaan-perbedaanku dengan } \\
\text { orang lain }\end{array}$ & & 10 & & & & 2 \\
\hline 7. & $\begin{array}{l}\text { menerima segala kekurangan yang ada pada } \\
\text { diriku sendiri }\end{array}$ & & & & & & 10 \\
\hline 8. & menghargai keadaan diriku sendiri apa adanya & 21 & 15 & & 15 & 19 & 7 \\
\hline 10. & berani tampil dengan lebih percaya diri & 9 & 22 & 11 & 9 & 17 & 5 \\
\hline 12. & $\begin{array}{l}\text { berani mengungkapkan ide-ide/gagasanku } \\
\text { sendiri }\end{array}$ & 20 & & 15 & & & \\
\hline
\end{tabular}




\begin{tabular}{|c|c|c|c|c|c|c|c|}
\hline $\begin{array}{l}\text { No } \\
\text { Butir }\end{array}$ & $\begin{array}{l}\text { AKU BUTUH BIMBINGAN AGAR DAPAT: } \\
\qquad \mathrm{N}=\end{array}$ & $\begin{array}{c}\text { Wiro- } \\
\text { brajan } \\
(127)\end{array}$ & $\begin{array}{l}\text { Me- } \\
\text { jing } \\
(71)\end{array}$ & $\begin{array}{l}\mathrm{Pa}- \\
\operatorname{tran} \\
(47)\end{array}$ & $\begin{array}{l}\text { Tlo- } \\
\text { go } \\
(48) \\
\end{array}$ & $\begin{array}{c}\text { Nge- } \\
\text { bel } \\
(65)\end{array}$ & $\begin{array}{l}\text { Baci- } \\
\text { ro } \\
(119) \\
\end{array}$ \\
\hline 19. & $\begin{array}{l}\text { memiliki kepedulian untuk membantu teman- } \\
\text { temanku yang mengalami kesulitan }\end{array}$ & 15 & 8 & 23 & 17 & 10 & \\
\hline 31. & $\begin{array}{l}\text { melakukan aktivitas pokok dalam belajar } \\
\text { (seperti: membaca, menulis, berhitung) dengan } \\
\text { cepat }\end{array}$ & 6 & 3 & 8 & 3 & 2 & \\
\hline 32. & memahami penjelasan guru ketika mengajar & 5 & 2 & 4 & 7 & 4 & \\
\hline 33. & mengikuti petunjuk guru secara tepat & 10 & 7 & 5 & 6 & 5 & 4 \\
\hline 34. & $\begin{array}{l}\text { mengatur antara kegiatan belajar, tugas-tugas } \\
\text { sekolah, dengan kegiatan-kegiatan bermain } \\
\text { secara seimbang }\end{array}$ & 2 & 4 & 2 & 1 & 1 & 1 \\
\hline 35. & mengerti cara-cara belajar yang baik & 7 & 6 & 14 & 5 & 7 & 6 \\
\hline 36. & memperbaiki kebiasaan-kebiasaan belajarku yang & 13 & 5 & 19 & 24 & 16 & \\
\hline 37. & $\begin{array}{l}\text { berani bertanya kepada guru ketika aku tidak } \\
\text { paham }\end{array}$ & 11 & 18 & 9 & 21 & 25 & \\
\hline 38. & $\begin{array}{l}\text { menerapkan strategi belajar yang tepat dalam } \\
\text { menghadapi ujian/ulangan-ulangan }\end{array}$ & 8 & 11 & 3 & 8 & 9 & 12 \\
\hline 39. & $\begin{array}{l}\text { memperoleh informasi yang lengkap tentang } \\
\text { pilihan sekolah lanjutan (SMP) }\end{array}$ & 4 & & 1 & 4 & 6 & \\
\hline 40. & $\begin{array}{l}\text { memahami usaha-usaha mempersiapkan diri } \\
\text { dalam melanjutkan sekolah }\end{array}$ & 12 & 13 & 6 & 11 & 11 & 13 \\
\hline 41. & $\begin{array}{l}\text { membiasakan diri untuk gemar membantu } \\
\text { pekerjaan orang tua sehari-hari di rumah. }\end{array}$ & 14 & 12 & 22 & 14 & 14 & \\
\hline 49. & $\begin{array}{l}\text { melaksanakan dengan tertib } \\
\text { keputusan/rencana-rencana yang telah kususun } \\
\text { sendiri }\end{array}$ & & & 18 & 19 & 21 & \\
\hline 52. & tekun beribadah sesuai dengan ajaran agamaku & 22 & 1 & 10 & 13 & 8 & 14 \\
\hline 54. & $\begin{array}{l}\text { membiasakan diri berperilaku positif terhadap } \\
\text { sesama }\end{array}$ & 18 & 9 & 12 & 22 & 18 & \\
\hline 57. & berani mengakui kesalahan secara ksatria & 25 & 31 & 13 & 18 & 28 & \\
\hline 59. & $\begin{array}{l}\text { berani bertanggung jawab atas akibat dari } \\
\text { perbuatanku }\end{array}$ & 16 & 16 & 16 & 10 & 12 & \\
\hline 60. & $\begin{array}{l}\text { belajar konsekuen terhadap janji-janji/ucapan- } \\
\text { ucapanku }\end{array}$ & 19 & 21 & 20 & 16 & 15 & \\
\hline
\end{tabular}

Keterangan: Angka pada kolom untuk setiap SD menggambarkan peringkat kebutuhan. 
Berdasarkan butir kebutuhan terintens yang teridentifikasi di atas, disusunlah kurikulum bimbingan klasikal untuk masing-masing SD. Dalam evaluasi pada akhir pelaksanaan program dengan menggunakan IKPM yang sama, jika terjadi penurunan peringkat berarti pelayanan bimbingan cukup efektif. Dengan demikian, instrumen IKPM dapat digunakan sebagai sarana perancangan kurikulum dan evaluasi BK di SD.

\section{Simpulan}

Instrumen Inventori Kebutuhan Perkembangan Murid (IKPM) yang diujikembangkan dalam penelitian ini, berdasarkan pertimbangan pakar dan penilaian para praktisi/pengguna (60 orang Guru Kelas V dan VI SD) serta didukung oleh bukti-bukti empirik yang menggambarkan keterpenuhan validitas konstruk, tingkat reliabilitas, dan kriteria fit model pengukurannya dapat disimpulkan telah memenuhi syarat sebagai salah satu instrumen pengungkap kebutuhan perkembangan murid kelas V \& VI SD. Inventori ini dapat digunakan oleh Guru Kelas untuk menghimpun data asesmen kebutuhan murid dalam rangka penyusunan kurikulum bimbingan (guidance curriculum), sekaligus dapat digunakan sebagai instrumen evaluasi program yang dilaksanakan pada akhir tahun pelayanan. Implementasi penggunaan instrumen ini pada 16 kelas di SD ternyata dapat menghasilkan deskripsi butir-butir kebutuhan perkembangan murid yang teridentifikasi intens dan sangat intens untuk direkomendasikan sebagai muatan kurikulum bimbingan klasikal pada kelas-kelas tinggi di SD.

\section{Daftar Pustaka}

American Educational Research Association. (1999). Standards for educational and psychological testing. Washington: AERA-APA.

Brinkerhoff, R.O., et al., (1986). Program evaluation a practitioner's guide for trainers and educators. Boston: Kluwer-Nijhoff Publishing. 
Brown, D. \& Trusty, J. (2005). Designing and leading comprehensive school counseling programs, promoting student competence and meeting student needs. USA: Thomson Brools/Cole.

Dean, D.L. (1994). How to use focus groups. In J.S.Wholey, H.P.Hatry, \& K.E.Newcomer (Eds.), Hanbook of praktical program evaluation. San Francisco: Jossey-Bass Publishers.

Erford, B.T. (2007). Transforming the school counseling profession (Second Edition). New Jersey: Pearson Merrill Prentice Hall.

Hargreaves, D. (1982). The challenge for the comprehensive school. London: Routladge and Kegan Paul.

Jones, V.F. \& Jones, L.S. (1998). Comprehensive classroom manajement. creating communities of support and solving problems. Boston: Allyn and Bacon.

Joreskog, K. \& Sorbom, D. (1993). Lisrel. 8: Structural equation modeling with the simplis command language. Chicago: Scientific Software International.

Linn, R.L. (1989). Educational measurement. ( $3^{\text {rd }}$ ed). New York: Macmillan Publishing Company.

Linstone, H.A. \& Turoff, M. (2002). The delphi method techniques and applications. Electronic version.

Mardapi, Djemari, 2008) Teknik penyusunan instrumen tes dan nontes. Jogjakarta: Mitra Cendikia.

Nurgiyantoro, B., Gunawan, \& Marzuki. (2000). Statistik terapan untuk penelitian ilmu-ilmu sosial. Yogyakarta: Gajah Mada University Press. 
Jurnal Penelitian dan Evaluasi Pendidikan

Peraturan Menteri Pendidikan Nasional Republik Indonesia nomor 22 Tahun 2006 tentang Standar isi satuan pendidikan dasar dan menengah.

Plomp,T. (1999). Design methodology and developmental research in/on education and training. Twente University. Netherlands

Puskur Depdiknas. (2006). Buku panduan pengembangan diri untuk satuan pendidikan dasar dan menengah. Jakarta: BSNP dan Puskur Depdiknas RI.

Sink, A.C. (2005). Contemporary school counseling: Theory, research, and practice. Boston: Lahaska Press Houghton Mifflin.

Solimun. (2002). Structural Equation Modeling (SEM) Lisrel dan Amos. Malang: Fakultas MIPA Universitas Brawijaya.

Sugiyono. (2008). Metode penelitian pendidikan pendekatan kuantitatif, kualitatif, dan $R \& D$. Bandung: Alfabeta.

46 - Jurnal Penelitian dan Evaluasi Pendidikan Tahun 15, Nomor 1, 2011 